\title{
Urgensi Perumusan Perbuatan Memperdagangkan Pengaruh sebagai Tindak Pidana Korupsi
}

\author{
Imentari Siin Sembiring, ${ }^{\star}$ Elly Sudarti, ${ }^{\star \star}$ Andi Najemi ${ }^{\star \star \star}$ \\ Fakultas Hukum Universitas Jambi \\ *imentarisiins@gmail.com

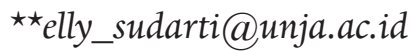

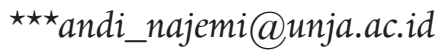

\begin{abstract}
This article discusses the act of trading in influence as a form of corruption as regulated in the United Nations Convention Against Corruption (UNCAC) but has not been implemented into Indonesian criminal law even though it was ratified in 2006. Trading in influence is a form of trilateral relationship of corruption which involves at least three parties, namely an influential party, a party that has the authority, and an interest. This article concludes, the formulation of trading influence as a criminal act of corruption is urgent in three aspects. First, the regulation in national law is a form of transformation of UNCAC provisions that have been ratified. Second, several cases of corruption so far, as in the two cases discussed here, actually show a form of trading in influence, even though law enforcement is imposed with bribery. Third, efforts to impose actors of trading in influence with the bribery Article as so far, are actually limited to actors who are state administrators or civil servants; in the event that the actor is not part of the two, the subjective elements of bribery Article are not fulfilled. Therefore, in the future criminal law policy, it is necessary to accommodate the formulation of trading in influence as a criminal act of corruption, in this case offered through the revision of the Corruption Eradication Act.
\end{abstract}

Keywords: corruption; trading in influence; criminal act. 


\section{Abstrak}

Artikel ini membahas perbuatan memperdagangkan pengaruh sebagai salah satu bentuk korupsi sebagaimana diatur dalam United Nations Convention Against Corruption (UNCAC) namun belum diimplementasikan dalam hukum pidana Indonesia meski telah diratifikasi pada 2006. Memperdagangkan pengaruh sebagai bentuk trilateral relationship merupakan bentuk korupsi yang melibatkan sedikitnya tiga pihak, yaitu pihak yang berpengaruh, pihak yang memiliki kewenangan, serta pihak yang memiliki kepentingan. Artikel ini menyimpulkan, perumusan perbuatan memperdagangkan pengaruh sebagai tindak pidana korupsi urgen dalam tiga hal. Pertama, pengaturannya dalam hukum nasional merupakan bentuk dari transformasi ketentuan UNCAC yang sudah diratifikasi. Kedua, beberapa kasus korupsi selama ini, sebagaimana dalam dua kasus yang dibahas di sini, sebenarnya menunjukkan adanya bentuk memperdagangkan pengaruh, sekalipun pada akhirnya dijerat penegak hukum dengan suap. Ketiga, upaya menjerat pelaku memperdagangkan pengaruh dengan Pasal tentang suap sebagaimana yang selama ini dikenakan, sesungguhnya terbatas pada pelaku yang merupakan penyelenggara negara atau pegawai negeri; dalam hal pelaku bukan bagian dari keduanya maka unsur subjektif dari Pasal suap tidak terpenuhi. Karena itu, dalam kebijakan hukum pidana ke depan, perlu diakomodasi perumusan memperdagangkan pengaruh sebagai tindak pidana korupsi, dalam hal ini didorong melalui revisi Undang-Undang Pemberantasan Tindak Pidana Korupsi.

Kata kunci: korupsi; memperdagangkan pengaruh; tindak pidana.

\section{A. Pendahuluan}

Artikel ini membahas urgensi perumusan perbuatan memperdagangkan pengaruh sebagai tindak pidana korupsi. Undang-Undang Nomor 20 Tahun 2001 tentang Perubahan atas Undang-Undang Nomor 31 Tahun 1999 tentang Pemberantasan Tindak Pidana Korupsi (selanjutnya disebut UU PTPK) yang merupakan dasar hukum pemberantasan korupsi di Indonesia masih menyisakan beragam persoalan, salah satunya tentang perbuatan memperdagangkan pengaruh yang tidak ikut diatur di dalamnya. Artikel ini membangun argumentasi bahwa perbuatan memperdagangkan pengaruh sebagai 
tindak pidana korupsi perlu diatur dalam hukum pidana korupsi, utamanya melalui revisi UU PTPK. Selain alasan kasus berkaitan memperdagangkan pengaruh sudah ada, Indonesia juga sebenarnya terikat dengan Konvensi Internasional yang di dalamnya mengatur perbuatan memperdagangkan pengaruh sebagai tindak pidana korupsi.

Konvensi yang mengatur perbuatan memperdagangkan pengaruh sebagai tindak pidana korupsi Ketentuan memperdagangkan pengaruh sendiri bermula ketika Persatuan Bangsa-Bangsa (PBB) merumuskan konvensi melawan korupsi di Meksiko pada 2003 melalui United Nations Convention Against Corruption (UNCAC). Konvensi ini lahir sebagai perwujudan dari kekhawatiran dunia akan maraknya perbuatan korupsi dengan modus operandi yang terus berkembang dan menjadi lebih kompleks dari perbuatan korupsi yang sebelumnya telah diatur dalam hukum positif. Indonesia telah meratifikasi UNCAC melalui Undang-Undang Nomor 7 Tahun 2006 tentang Pengesahan United Nations Conventian Against Corruption 2003. Bagi suatu negara, meratifikasi suatu perjanjian internasional berarti negara tersebut telah mengikatkan diri serta tunduk pada isi (hak dan kewajiban) yang terkandung di dalamnya. ${ }^{1}$ Namun demikian, pasca ratifikasi hingga saat ini, Indonesia belum melakukan proses transformasi ke dalam peraturan perundang-undangan.

Di Indonesia, perbuatan memperdagangkan pengaruh telah terjadi beberapa kali, misalnya kasus kuota impor daging sapi dan kasus jual beli jabatan di Kementerian Agama, yang nanti dalam pembahasan diuraikan lebih lanjut. Meski pada kenyataannya kasus ini diputus pengadilan sebagai perbuatan suap-menyuap, sebenarnya muncul berbagai persoalan terkait hal tersebut. Adanya kasus yang terjadi, yang di dalamnya ada memperdagangkan pengaruh, menunjukkan bahwa persoalan terkait memperdagangkan pengaruh sesungguhnya penting dibahas dalam konteks hukum pidana Indonesia.

1 Alvin Saputra dan Ahmad Mahyani, "Tinjauan Yuridis Trading in Influence dalam Tindak Pidana Korupsi”, Mimbar Keadilan: Jurnal Ilmu Hukum (2017), hlm. 82 . 
Kenyataan tersebut menunjukkan bahwa hukum itu ketinggalan dari peristiwa yang terjadi di masyarakat, dan ini menggambarkan upaya pemberantasan korupsi yang berlangsung di Indonesia. Modus dan pelaku kejahatan korupsi mengalami perubahan yang signifikan dari waktu ke waktu, namun tidak diiringi dengan perbaikan aturan yang memadai untuk menjangkau perkembangan kejahatan. ${ }^{2}$ Padahal, dengan adanya Konvensi Internasional mengenai pemberantasan korupsi, sudah seharusnya ketentuan pemberantasan korupsi dalam hukum nasional ikut menyesuaikan dan menyelaraskannya. ${ }^{3}$

Kebijakan hukum pidana sebagai suatu usaha untuk mewujudkan peraturan perundang-undangan pidana yang sesuai dengan keadaan dan situasi pada waktu dan untuk masa-masa yang akan datang ${ }^{4}$ diharapkan dapat menjadi langkah untuk memberantas tindak pidana korupsi. Sebagaimana dikatakan Barda Nawawi Arief, upaya pembaruan hukum pidana pada hakikatnya merupakan suatu upaya untuk melakukan reorientasi dan reformasi hukum pidana yang sesuai dengan nilai-nilai sosio-politik, sosio-filosofik, dan sosiokultural masyarakat Indonesia. Karena itu pembaruan hukum pidana harus ditempuh dengan pendekatan yang berorientasi kebijakan (policy oriented approach) dan nilai (value oriented approach) sekaligus. ${ }^{5}$

Berdasarkan persoalan yang telah diuraikan, artikel ini membahas lebih lanjut tentang perbuatan memperdagangkan pengaruh sebagai tindak pidana korupsi. Ruanglingkup artikel ini adalah urgensi pengaturan perbuatan memperdagangkan pengaruh sebagai tindak pidana korupsi dan faktor penghambat implementasi pengaturannya di Indonesia. Dengan cakupan bahasan demikian, diharapkan dapat dijelaskan mengapa dalam kebijakan hukum pidana nasional ke depan

2 Sahuri Lasmadi, Usman, dan Elly Sudarti, "Modus Operandi Pelaku Tindak Pidana Korupsi yang Dilakukan Anggota DPR dalam Pelepasan Kawasan Hutan Lindung Pantai Air Telang Kabupaten Banyuasin Sumatera Selatan”, Jurnal Komunikasi Hukum, 5, 1 (2019), hlm. 4.

3 Andi Hamzah, Pemberantasan Korupsi Melalui Hukum Pidana Nasional dan Internasional (Jakarta: Rajawali Pers, cetakan ketujuh, 2015), hlm. 234.

4 Dey Ravena dan Kristina, Kebijakan Kriminal (Criminal Policy) (Jakarta: Kencana, 2017), hlm. 125.

5 Barda Nawawi Arief, Bunga Rampai Kebijakan Hukum Pidana (Bandung: Citra Aditya Bakti, 1996), hlm. 30-32. 
perlu diupayakan untuk mengatur perbuatan memperdagangkan pengaruh sebagai tindak pidana korupsi.

\section{B. Urgensi Pengaturan Memperdagangkan Pengaruh di Indonesia}

Dalam artikel ini, perumusan memperdagangkan pengaruh di Indonesia sebagai tindak pidana korupsi dinilai urgen dalam tiga hal. Pertama, sebagaimana disampaikan dalam Pendahuluan, pemerintah Indonesia telah meratifikasi UNCAC, yang merupakan Konvensi yang mengatur perbuatan memperdagangkan pengaruh sebagai tindak pidana korupsi. Dengan ratifikasi yang sudah dilakukan, maka sudah semestinya pemerintah Indonesia mentransformasikan ketentuan dalam UNCAC, termasuk tentang memperdagangkan pengaruh sebagai tindak pidana korupsi, ke dalam hukum nasional. Proses transformasi ke dalam hukum nasional sendiri, sebagaimana disebutkan Hikmahanto Juwana, sesungguhnya salah satu dari dua kewajiban suatu negara dalam proses ratifikasi perjanjian internasional, selain penyelarasannya dengan Konstitusi. ${ }^{6}$

Dalam UNCAC, perbuatan memperdagangkan pengaruh diatur pada Pasal 18, yaitu:

Each State Party shallconsider adopting legislative and other measures as may be necessary to establish as criminal offences, when commited intentionally:

(a) The promise, offering or giving to a public official or any other person, directly or indirectly, of an undue advantage in order that the public official or the person abuse his or her real or supposed influence with a view to obtaining from an administration or public outhority of the State Party an undue advantage for the original instigator of the other person;

(b) The solicitation or acceptance by a public official or any other person, directly or indirectly, of an undue advantage for himself or herself or for another person in order that the public official or the person abuse his or

6 Hikmahanto Juwana, "Kewajiban Negara dalam Proses Ratifikasi Perjanjian Internasional: Memastikan Keselarasan dengan Konstitusi dan Mentransformasikan ke Hukum Nasional”, Undang: Jurnal Hukum, 2, 1 (2019): 1-24. 
her real or supposed influence with a view to obtaining from an administration or public auhority of the State Party an undue advantage.

Dari ketentuan Pasal 18 UNCAC ini, maka perbuatan memperdagangkan pengaruh mengandung unsur-unsur sebagai berikut:

1. Frasa "Each State Party shall consider adopting..." menggambarkan sifat non-mandatory offences dari ketentuan memperdagangkan pengaruh. Ini berarti kriminalisasi perbuatan memperdagangkan pengaruh bukan menjadi kewajiban negara peserta ratifikasi, melainkan diserahkan kepada masing-masing negara dengan melihat situasi masing-masing.

2. Frasa “...intensionally..." menggambarkan bentuk kesalahan dari ketentuan memperdagangkan pengaruh berupa kesengajaan yang mengharuskan adanya kehendak dan pengetahuan (wilens en wetens $)^{7}$ dari pelaku.

3. Frasa "The promise, offering or giving..." pada huruf a merujuk pada bentuk aktif dari perbuatan memperdagangkan pengaruh yang pada hakikatnya merupakan upaya atau tawaran kepada seseorang agar menyalahgunakan pengaruhnya. Sedangkan frasa "the solicitation or aceptance..." merupakan bentuk pasif dari perbuatan memperdagangkan pengaruh yang berupa penerimaan tawaran dari seseorang untuk menyalahgunakan pengaruhnya.

4. Frasa "...real or supposed influence..." mengadung arti bahwa tidak mutlak harus ada penyalahgunaan pengaruh yang nyata namun cukup dengan anggapan bahwa perbuatan tersebut merupakan penyalahgunaan pengaruh.

5. Frasa "...public official or any other people..." menunjukan unsur subjek hukum dari perbuatan memperdagangkan pengaruh tidak mensyaratkan status sebagai pejabat publik. Ini artinya pelaku tidak terbatas hanya pada pejabat publik tetapi juga mengikat bagi setiap orang.

6. Frasa "...undue advantage..." merupakan imbalan atas perbuatan

7 Zainal Abidin Farid, Hukum Pidana 1 (Jakarta: Sinar Grafika, cetakan keempat, 2014), hlm. 269. 
memperdagangkan pengaruh serta tujuan dari perbuatan memperdagangkan pengaruh. Imbalan dalam hal ini dapat berupa jabatan atau imbalan materil lainnya.

Dari uraian barusan maka dapat dikatakan, memperdagangkan pegaruh atau trading in influence merupakan janji atau pemberian atau penerimaan kepada siapa pun baik secara langsung maupun tidak langsung dengan maksud agar orang tersebut menyalahgunakan pengaruhnya kepada pejabat publik agar memperoleh keuntungan yang tidak semestinya dari tindakan pejabat publik untuk kepentingan pihak ketiga.

Association of Accredited Public Poly Advocates to the European Union menerangkan, memperdagangkan pengaruh sebagai situasi saat seseorang menggunakan pengaruhnya kepada pejabat publik dalam proses pengambilan keputusan untuk kepentingan pihak ketiga dengan imbalan kesetiaan, uang atau keuntungan material lainnya. Dalam Oxford Dictionary, sebagaimana dikutip Fitroh Rohcahyanto, memperdagangkan pengaruh merupakan bentuk penggunakan posisi atau pengaruh politik atas nama seseorang dengan imbalan uang atau bantuan lain. ${ }^{8}$ Frasa penggunaan posisi mengandung arti bahwa pengaruh dilakukan oleh pihak yang berkuasa, sedangkan penggunaan pengaruh politik atas nama seseorang berarti perbuatan tersebut dilakukan menggunakan jalur kedekatan dengan pihak yang

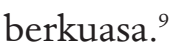

Perbuatan memperdagangkan pengaruh merupakan korupsi dengan bentuk trilateral relationship karena melibatkan tiga pihak yakni pihak yang berkepentingan, pihak yang berpengaruh, dan pihak yang dipengaruhi. Indonesia Corruption Watch (ICW) mengklasifikasi perbuatan memperdagangkan pengaruh ke dalam tiga pola: vertikal, vertikal dengan broker, dan horizontal. ${ }^{10}$ Pada pola vertikal, pihak yang berpengaruh merupakan pemilik kekuasaan sehingga memiliki

8 Fitroh Rohcahyanto, "Memperdagangkan Pengaruh Sebagai Tindak Pidana Korupsi” (disertasi, Universitas Airlangga, Surabaya, 2018), hlm. 24.

9 Rohcahyanto, "Memperdagangkan Pengaruh", 24.

10 ICW, "Kajian Implementasi Aturan Memperdagangkan Pengaruh”, hlm. 29-33. 
kewenangan dalam pengambilan kebijakan untuk kepentingan orang tertentu atau kelompok tertentu. Bentuk seperti ini tidak masuk dalam kategori trilateral relationship karena hanya melibatkan dua pihak yang mana pihak yang berkepentingan langsung berhubungan dengan pihak yang memiliki kewenangan atau kekuasaan.

Pada pola vertikal dengan broker, hubungan para pihak dalam perbuatan memperdagangkan pengaruh disertai broker. Perantara atau broker menjadi pihak yang memanfaatkan pengaruh pejabat publik. Pola vertikal dengan broker juga tidak memenuhi unsur trilateral relationship karena pada kenyataannya perantara atau broker tidak memiliki pengaruh apa pun dalam pengambilan keputusan namun memanfaatkan pengaruh pejabat publik atau orang lain untuk memenuhi kepentingan dari pihak lain. Pada pola horizontal, bentuk perbuatan memperdagangkan pengaruh pada dasarnya telah memenuhi unsur trilateral relationship. Pihak yang berkepentingan dan pihak yang memiliki pengaruh menjadi pihak yang aktif, sementara pejabat publik merupakan pihak yang dipengaruhi, artinya pengambilan keputusan oleh pejabat publik didasari atas pengaruh seseorang untuk kepentingan pihak lain.

Mantan hakim agung Artidjo Alkostar menyatakan, pengaruh dalam perbuatan memperdagangkan pengaruh merupakan suatu tekanan yang dapat mempengaruhi sikap seseorang dalam menentukan pendapatnya, tekanan yang dimaksud dapat berupa tekanan kekuasaan politik atau tekanan ekonomi. ${ }^{11}$ Jika dihubungkan dengan memperdagangkan pengaruh yang diatur dalam UNCAC, maka seseorang yang memiliki pengaruh tidak terbatas pada pejabat publik yang memiliki kekuasaan secara langsung namun bisa siapa saja yang memiliki kapasitas untuk mempengaruhi otoritas publik.

Kedua, pada kenyatannya, kasus berkaitan dengan memperdagangkan pengaruh telah terjadi beberapa kali di Indonesia. Dalam

11 Donal Faris, Almas Sjafrina, Era Purnama sari, dan Wahyu Nandang Herawan, Kajian Implementasi Aturan Memperdagangkan Pengaruh dalam Hukum Nasional (Jakarta: Indonesia Corruption Watch, Lembaga Bantuan Hukum Padang, dan Yayasan Lembaga Bantuan Hukum Indonesia, 2014), hlm. 45. 
artikel ini dipaparkan dua kasus yang berkaitan dengan perbuatan memperdagangkan pengaruh. Kasus pertama adalah kasus kuota impor daging sapi dengan terpidana Lutfi Hasan Ishaq (LHI). Pada putusan tingkat pertama sampai kasasi, perbuatan LHI dinyatakan memenuhi unsur Pasal 12 huruf a UU PTPK jo. Pasal 55 KUHP. Perlu diperhatikan pertimbangan hakim terkait kedudukan subjek hukum dan kewenangan terdakwa. LHI dinyatakan memenuhi unsur pegawai negeri atau penyelenggara negara dengan berdasarkan dua fakta hukum yaitu sebagai anggota Dewan Perwakilan Rakyat (DPR) periode 2009-2014 dan Presiden Partai Keadilan Sejahtera (PKS). ${ }^{12}$ Selanjutnya unsur berbuat atau tidak berbuat sesuatu dalam jabatannya, pemberian suap oleh Maria Elizabeth Liman (MEL) dimaksudkan agar LHI menggunakan jabatannya dalam memengaruhi pejabat di Kementerian Pertanian yang dipimpin oleh Suswono, yang merupakan anggota Majelis Syuro PKS, supaya meloloskan pemohonan penambahan kuota impor daging sapi yang diajukan oleh PT. Indoguna Utama dan anak perusahaannya. ${ }^{13}$

Di DPR, LHI merupakan anggota komisi I dengan lingkup tugas pertahanan, luar negeri, komunikasi dan informatika, dan intelijen. Pada kasus impor daging sapi, LHI tidak memiliki kewenangan terhadap penambahan kuota impor daging. Begitu pula, jabatannya selaku Presiden PKS tidak berhubungan dengan anggaran negara serta tidak memiliki korelasi apapun dengan unsur penyelenggara negara. Oleh karena itu kedudukan LHI baik sebagai anggota DPR maupun sebagai Presiden PKS sebenarnya tidakmemilikikewenangan atau berkaitan dengan mengatur kebijakan impor daging. Karena itu, pemberian suap oleh MEL kepada LHI tidak berkaitan dengan kewenangan LHI selaku anggota Komisi I DPR, melainkan posisinya sebagai Presiden PKS, yang diyakini memiliki pengaruh terhadap Menteri Pertanian yang merupakan kader PKS dalam mengambil kebijakan terkait penambahan kuota impor daging. Oleh karena itu MEL menjanjikan akan memberi dukungan dan bantuan dana

12 Putusan Nomor 38/PID.SUS /TPK/2013/PN.JKT.PST, hlm. 681-683.

13 Putusan Nomor 1195 K/Pid.Sus/2014, hlm. 14. 
kepada PKS. ${ }^{14}$ Berdasarkan fakta tersebut, maka penerapan Pasal suap pada kasus ini sebenarnya tidaklah tepat.

Penilaian tersebut tidak berarti meniadakan unsur pidana terhadap pebuatan LHI yang telah terbukti menerima uang sejumlah Rp. 1.3 Milyar dan berhasil memengaruhi penambahan kuota impor daging atas PT. Indoguna Utama. Oleh karena itu implementasi memperdagangkan pengaruh penting untuk segera dilakukan agar tidak ada kesalahan dalam penerapan pasal dalam kasus korupsi. Pada Gambar 1 terlihat skema hubungan para pihak pada kasus penambahan kuota impor daging.

Gambar 1. Pola memperdagangkan pengaruh kasus kuota impor daging

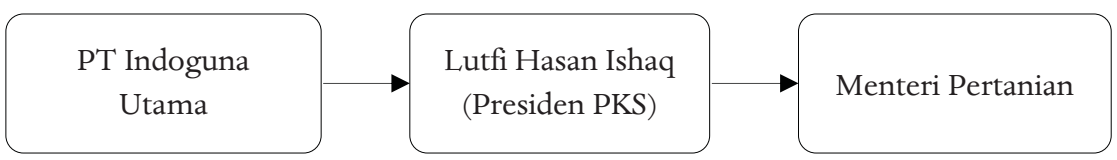

Kasus kedua ialah kasus korupsi yang melibatkan Muchammad Romahurmuziy (Rommy) yang diputus bersalah oleh Pengadilan Negeri Jakarta Pusat. Rommy divonis melanggar Pasal 11 UU PTPK jo Pasal 55 ayat (1) jo Pasal 64 ayat (1) KUHP dengan Putusan Nomor 87/Pid.Sus/TPK/2019/PN.Jkt karena menerima suap senilai Rp. 325 juta dari Haris Hasanudin (HS) dan Rp. 91.4 juta dari Muafaq Wirahadi (MW).

Sama halnya dengan kasus LHI, dalam kasus ini kedudukan Rommy baik selaku anggota Komisi XI DPR maupun sebagai Ketua Partai Persatuan Pembangunan (PPP) sebenarnya tidak memiliki kewenangan secara langsung dalam pengangkatan jabatan di wilayah Kementerian Agama. Terkait dengan unsur "padahal patut diketahui atau patut diduga bahwa hadiah atau janji diberikan karena kekuasaan atau kewenangan yang berhubungan dengan jabatannya atau menurut pikiran orang yang memberikan hadiah atau janji tersebut ada hubungan dengan jabatannya", majelis hakim pada putusan berkesimpulan bahwa selaku Anggota DPR sekaligus Ketua Partai,

14 Putusan Nomor 1195 K/Pid.Sus/2014, hlm. 5-7. 
Rommy melakukan intervensi kepada Lukman Hakim Saifudin (LHS) yang merupakan Menteri Agama RI dalam proses pemilihan seleksi Pejabat Tinggi Pratama di lingkungan Kementerian Agama serta menerima sejumlah uang dari HS dan MW. ${ }^{15}$

Pada eksepsinya, Romahurmuziy berdalih bahwa usulan kepada LHS selaku Menteri Agama terkait nominasi HS dan MW di lingkungan kantor Wilayah Kementerian Agama Jawa Timur merupakan perwujudan dari fungsi representasi selaku anggota DPR. Padahal jika benar demikian maka tidak seharusnya ada pemberian uang dari HS dan MW kepada Rommy. HS dan MW memberikan sejumlah uang kepada Rommy untuk melancarkan proses seleksi jabatan di Kementerian Agama, di mana HS ingin menjadi Kepala Kantor Wilayah Kementerian Agama Jawa Timur sedangkan MW ingin mendapat posisi Kepala Kementerian Agama Gresik. ${ }^{16}$ Rommy sebagai anggota DPR pada Komisi XI yang membidangi keuangan, perbankan, dan bidang finansial, sesungguhnya tidak memiliki kewenangan dalam seleksi jabatan di Kementerian Agama sehingga seharusnya tidak dapat dikenakan pasal suap. Dalam kasus ini, Rommy menyalahgunakan pengaruhnya sebagai Ketua PPP untuk kepentingan HS dan MW terhadap LHS yang merupakan anggota PPP sekaligus Menteri Agama yang memiliki kekuasaan dalam pengangkatan dan pemberhentian di lingkungan Kementerian Agama.

Gambar 2. Pola memperdagangkan pengaruh dalam pengangkatan dan pemberhentian pejabat

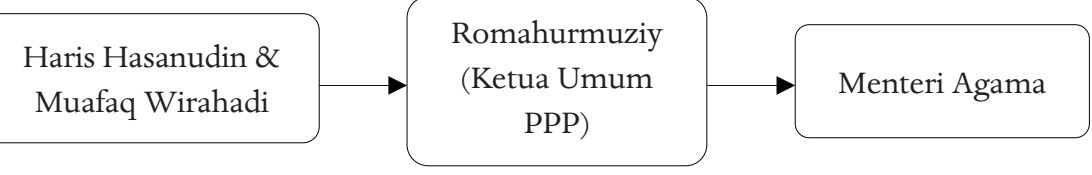

15 Putusan Nomor 87/Pid.Sus.TPK/2019/PN.Jkt.Pst, hlm. 507.

16 CNN Indonesia, "Eks Ketum PPP Romahurmuziy Divonis Dua Tahun Penjara”, https://www. cnnindonesia.com/nasional/2020012010193412-466884 / eks-ketum-ppp-romahurmuziy-divonis-dua-tahun-penjara, 20/1/2020, diakses 6/2/2020. 
Pada Gambar 2 terlihat hubungan para pihak dalam kasus Rommy, yang sesungguhnya termasuk kategori perbuatan memperdagangkan pengaruh dengan pola horizontal.

Dari dua kasus yang telah diuraikan, timbul pertanyaan, jika kasus tersebut masih dapat diproses secara hukum dan dikenakan pidana, lalu kenapa ketentuan memperdagangkan pengaruh tetap menjadi penting untuk diupayakan. Dalam kaitannya dengan hal tersebut muncul pertanyaan yang sama, bagaimana jika para terdakwa dalam kasus tersebut bukan merupakan seorang penyelenggara negara, apakah dapat kasus tersebut diproses secara hukum, ataukah kasus tersebut dapat diproses melalui ketentuan pasal-pasal dalam UU PTPK. Jawaban dari pertanyaan tersebut tentu tidak, padahal kasuskasus demikian terus terjadi dengan modus yang berbeda-beda.

Ketiga, sebagaimana yang barusan diungkapkan, perumusan perbuatan memperdagangkan pengaruh sebagai tindak pidana korupsi menjadi urgen karena tentu tidak selamanya subyek yang melakukannya adalah penyelenggara negara atau pegawai negeri. Selama ini, karena adanya kekosongan hukum berkaitan dengan perbuatan memperdagangkan pengaruh, maka penegak hukum menggunakan pasal suap untuk menjerat pelakunya, meski kasus tersebut sangat kental dengan perbuatan memperdagangkan pengaruh. Berdasarkan kasus-kasus yang telah diputus melalui proses peradilan, pelaku merupakan pegawai negeri atau penyelenggara negara sebagai subjek pelaku dalam tindak pidana korupsi, sehingga memang dimungkinkan untuk diproses melalui UU PTPK. Namun pertanyaannya, sampai kapan penegak hukum akan menggunakan Pasal suap untuk mengakomodasi perbuatan memperdagangkan pengaruh, dan bagaimana jika pelaku dari perbuatan memperdagangkan pengaruh bukan merupakan penyelenggara negara atau pegawai negeri. Dalam hal yang disebut terakhir, tentu tidak bisa dijerat dengan UU PTPK, disebabkan tidak memenuhi unsur subjektif dari Pasal suap yang mensyaratkan status pelaku sebagai penyelenggara negara atau pengawai negeri.

Berbagaipersoalan tersebutmenunjukkan perumusan perbuatan memperdagangkan pengaruh sebagai tindak pidana korupsi ke dalam 
hukum positif urgen dan mendesak untuk diupayakan. Terlebih dalam hukum pidana berlaku prinsip lex certa, yang menghendaki suatu aturan hukum harus dirumuskan secara tegas sehingga tidak ada ambiguitas dalam penerapannya.

\section{Faktor Penghambat Pengaturan dan Implementasi Memperdagangkan Pengaruh dalam Hukum Pidana Korupsi di Indonesia}

Keberadaan pasal yang mengatur mengenai perbuatan memperdagangkan pengaruh sudah pernah diupayakan untuk diadopsi dalam Rancangan Kitab Undang-undang Hukum Pidana (RKUHP) oleh pemerintah, namun ketentuan tersebut tidak dijumpai pada Rancangan versi $2019 .{ }^{17}$ Upaya untuk mengatur perbuatan memperdagangkan pengaruh ke dalam revisi UU PTPK juga sudah beberapa kali dilakukan, misalnya dalam Pasal 7 Draft Rancangan. ${ }^{18}$ Namun demikian, hingga saat ini belum ada aturan yang dapat menjerat pelaku perbuatan memperdagangkan pengaruh sehinga penegak hukum mengkontruksikan dakwaan dengan menggunakan pasal lain dalam UU PTPK.

Dalam penerapan konsep memperdagangkan pengaruh atau trading in influence ke dalam produk hukum, hingga saat ini belum semua negara yang meratifikasi UNCAC mentransformasikannya ke dalam hukum nasional. Selain karena sifat non mandatory offences dari ketentuan Pasal 18 UNCAC yang mengatur mengenai perbuatan memperdagangkan pengaruh, penyebab lainnya adalah karena lobbying oleh para pelobi yang menjadi suatu profesi yang legal di beberapa negara. ${ }^{19}$

Penyebab utama belum diaturnya perbuatan memperdagangkan pengaruh ke dalam hukum positif termasuk Indonesia karena

17 Bagian ketiga Rancangan Undang-Undang Hukum Pidana Tahun 2019.

18 Indonesia Corruption Watch, "Naskah Akademik dan Rancangan UndangUndang tentang Pemberantasan Tindak Pidana Korupsi, Usul Inisiatif Masyarakat”, 2015, hlm. 170.

19 Brigita P. Manohara, Dagang Pengaruh: Trading in Influence di Indonesia (Jakarta: Rajawali Pers, 2017), hlm. 95. 
perbuatan tersebut sulit untuk dimengerti dan juga sulit untuk digambarkan bentuknya. ${ }^{20}$ Selain itu menurut Micheal Johnston yang dikutip oleh Fitroh, "ruang lingkup dari korupsi memperdagangkan pengaruh sulit untuk dispesifikasikan". ${ }^{21}$ Association of Accredited Public Policy Advocates to The European Union (AAELP) menyatakan hal yang senada terkait sulitnya konsep memperdagangkan pengaruh, yaitu "kesulitan untuk mengkriminalisasi perdagangan pengaruh adalah karena perbuatan itu merupakan perbuatan korupsi yang kabur. Seorang pejabat yang dipengaruhi sulit untuk dibuktikan karena karena hubungan antara subjek yang berbuat dan subjek yang dipengaruhi tidak begitu jelas sehingga sulit untuk diinvestigasi dan dibuktikan". ${ }^{22}$

Pada 10-14 Desember 2006, negara-negara yang meratifikasi konvensi menyelenggarakan Conference of States Party (CoSP) di Jordan-Dead Sea. Konferensi ini merupakan pedoman untuk meningkatkan kapabilitas serta kerja sama dari negara peserta konvensi dalam mewujudkan tujuan memberantas korupsi. Dari hasil konferensi ini dihasilkan delapan resolusi, di antaranya adalah review of implementation. ${ }^{23}$ Pada 14-16 Maret 2011, Indonesia mangajukan diri sebagai salah satu negara yang ditinjau oleh negara peserta lainnya (Uzbekistan dan United Kingdom) terkait pelaksanaan dari UNCAC. Hasil dari peninjauan tersebut menemukan banyak kelemahan dalam Undang-Undang Pemberantasan Tindak Pidana Korupsi, salah satu catatan pentingnya adalah Pasal 18 UNCAC tentang Trading in Influence yang sampai saat ini belum juga diakomdoasi. ${ }^{24}$

Association of Certified Fraud Examiners (ACFE), dalam Round Table Discussion bersama Badan Pemeriksa Keuangan (BPK)

20 Andreas Nathaniel Manalu, “Kriminalisasi 'Trading in Influence' melalui Ketentuan Suap (Analisis Putusan Perkara Tindak Pidana Korupsi No. 38/PID.SUS /TPK/2013/PN.JKT.PST atas Terdakwa Lutfi Hasan Ishaq", Anotasi Putusan Tindak Pidana Korupsi, (2015), hlm. 4.

21 Rohcahyanto, "Memperdagangkan Pengaruh", hlm. 24.

22 Rohcahyanto, "Memperdagangkan Pengaruh", hlm. 24.

23 ICW, "Kajian Implementasi Aturan Memperdagangkan Pengaruh", hlm. 16.

24 ICW, "Kajian Implementasi Aturan Memperdagangkan Pengaruh”, hlm. 16. 
berkesimpulan, pembentuk undang-undang perlu memformulasikan konstruksi hukum dan parameter perbuatan memperdagangkan pengaruh untuk menghindari miskonsepsi dalam pemberantasan tindak pidana korupsi agar dapat ditangani dengan tepat. ${ }^{25}$ Menurut Miko S. Ginting, upaya mengkriminalisasi perbuatan memperdagangkan pengaruh perlu memperhatikan kapasitas pelaku (subjek), perbuatan serta dampak dari perbuatan tersebut. Sejalan dengan hal tersebut, Andreas menyarankan adanya pemisahan antara tindak pidana penyuapan dengan perbuatan memperdagangkan pengaruh karena terdapat perbedaan konteks mendasar berkaitan dengan pengaturan, subjek hukum, bentuk dan penerimaan dari perbuatan memperdagangkan pengaruh. ${ }^{26}$

Bentuk trilateral relationship membedakan antara perbuatan memperdagangkan pengaruh dan penyuapan. Tindak pidana penyuapan pada dasarnya hanya melibatkan dua pihak, yaitu pihak yang menyuap atau pihak yang berkepentingan dan pihak yang disuap atau pihak yang memiliki kewenangan yakni penyelenggara negara atau pegawai negeri. Pihak yang menyuap dalam hal ini menjanjikan sesuatu pada penyelenggara negara atau pegawai negeri agar melakukan atau tidak melakukan sesuatu yang bertentangan dengan kewenangannya. Sementara, pada perbuatan memperdagangkan pengaruh, harus ada tiga pihak yang terlibat, di mana pihak yang berkepentingan tidak akan berhubungan secara langsung dengan pemilik kekuasaan melainkan melalui pihak lain yang memiliki pengaruh atau dianggap dapat mempengaruhi otoritas publik dalam pengambilan keputusan agar menguntungkan pihak yang memiliki kepentingan.

Apabila dalam praktiknya perbuatan yang sebenarnya memperdagangkan pengaruh dikenakan ketentuan suap, lalu apakah keduanya sebenarnya memiliki keterkaitan. Hasil evaluasi Group of

25 Association of Certified Fraud Examiner, "Trading in Influence, Telah Diratifikasi tetapi belum Diterapkan di Indonesia”, https: / / acfe-indonesia. or.id/2018/02/trading-in-influence-telah-diratifikasi-tetapi-belumditerapkan-di-indonesia/, 15/2/2018, diakses 31/1/2020.

26 Association of Certified Fraud Examiner, "Trading in Influence”. 
Tabel 1. Perbedaan memperdagangkan pengaruh dengan penyuapan dan gratifikasi

\begin{tabular}{|c|c|c|c|}
\hline & $\begin{array}{l}\text { Memperdagangkan } \\
\text { Pengaruh }\end{array}$ & Suap & Gratifikasi \\
\hline $\begin{array}{l}\text { Pihak yang } \\
\text { terlibat }\end{array}$ & $\begin{array}{l}\text { - Pihak yang memiliki } \\
\text { pengaruh (baik penga- } \\
\text { ruh politik maupun } \\
\text { pengaruh ekonomi). } \\
\text { - Pihak yang dipengaruhi } \\
\text { yaitu dari sisi pengambil } \\
\text { kebijakan. } \\
\text { - Pihak yang memiliki } \\
\text { kepentingan yang } \\
\text { menginginkan keun- } \\
\text { tungan dari suatu } \\
\text { kebijakan yang diambil } \\
\text { oleh pegawai negeri atau } \\
\text { penyelenggara negara. }\end{array}$ & $\begin{array}{l}\text { - Penerima suap } \\
\text { yang merupakan } \\
\text { pejabat publik atau } \\
\text { penyelenggara negara } \\
\text { - Pemberi suap yang } \\
\text { dapat berasal dari } \\
\text { penyenggara negara } \\
\text { ataupun pihak swasta. }\end{array}$ & $\begin{array}{l}\text { - Penerima } \\
\text { gratifikasi } \\
\text { harus pejabat } \\
\text { publik atau } \\
\text { penyelenggara } \\
\text { negara } \\
\text { - Pemberi } \\
\text { gratifikasi yang } \\
\text { dapat berasal } \\
\text { dari penyenggara } \\
\text { negara ataupun } \\
\text { pihak swasta. }\end{array}$ \\
\hline $\begin{array}{l}\text { Subjek } \\
\text { hukum }\end{array}$ & $\begin{array}{l}\text { Pihak yang berpengaruh } \\
\text { yaitu siapapun tanpa } \\
\text { mensyarakatkan status } \\
\text { sebagai penyelenggara } \\
\text { negara atau pejabat } \\
\text { publik. }\end{array}$ & $\begin{array}{l}\text { Penerima suap } \\
\text { harus merupakan } \\
\text { penyelenggara negara, } \\
\text { hakim, pegawai negari, } \\
\text { dan advokat. }\end{array}$ & $\begin{array}{l}\text { Penerima } \\
\text { gratifikasi harus } \\
\text { merupakan penye- } \\
\text { lenggara negara, } \\
\text { hakim, pegawai } \\
\text { negari, dan } \\
\text { advokat. }\end{array}$ \\
\hline $\begin{array}{l}\text { Bentuk } \\
\text { perbuatan }\end{array}$ & $\begin{array}{l}\text { Perbuatan pelaku tidak } \\
\text { bertentang dengan } \\
\text { kewenangannya. }\end{array}$ & $\begin{array}{l}\text { Perbuatan pelaku } \\
\text { yang bertentangan } \\
\text { dengan kewajiban atau } \\
\text { kewenangannya atau } \\
\text { menurut si pemberi } \\
\text { suap ada hubungan } \\
\text { dengan jabatan si } \\
\text { penerima. }\end{array}$ & $\begin{array}{l}\text { Perbuatan pelaku } \\
\text { yang bertentangan } \\
\text { dengan } \\
\text { kewajiban atau } \\
\text { kewenangannya } \\
\text { atau menurut si } \\
\text { pemberi gratifikasi } \\
\text { ada hubungan } \\
\text { dengan jabatan si } \\
\text { penerima. }\end{array}$ \\
\hline $\begin{array}{l}\text { Peneri- } \\
\text { maan }\end{array}$ & $\begin{array}{l}\text { Keuntungan yang tidak } \\
\text { semestinya. }{ }^{27}\end{array}$ & $\begin{array}{l}\text { Penerima suap } \\
\text { menerima sesuatu atau } \\
\text { janji. }\end{array}$ & $\begin{array}{l}\text { Penerima suap } \\
\text { menerima hadiah } \\
\text { atau janji. }\end{array}$ \\
\hline
\end{tabular}

States Against Corruption (GRECO) menyatakan, perbedaan antara memperdagangkan pengaruh dan penyuapan adalah, perbuatan

27 Menurut Julie Philip yang dikutip oleh Brigita P. Manohara, keuntungan yang tidak semestinya tersebut biasanya sesuatu yang memiliki nilai dan dapat dihitung. 
memperdagangkan pengaruh tidak memerlukan unsur berbuat atau tidak berbuat oleh pejabat publik tetapi perbuatan di mana pihak yang memiliki pengaruh membantu pihak yang berkepentingan dengan mengintervensi pejabat publik agar melalukan perbuatan yang diminta. ${ }^{28}$ Sepintas, perbuatan memperdagangkan pengaruh memang serupa dengan suap menyuap serta gratifikasi, namun jangkauan perbuatan memperdagangkan pengaruh lebih luas dibanding suap menyuap dan gratifikasi, karena menyangkaut "penyalahgunaan pengaruh" bukan "berbuat atau tidak berbuat". ${ }^{29}$ Pada hakikatnya perbuatan memperdagangkan pengaruh merupakan delictum sui generis, yaitu tindak pidana yang berdiri sendiri, sehingga perbuatan ini tetap dapat terjadi dengan atau tanpa suap. ${ }^{30}$ Secara skematis, perbedaan antara memperdagangkan pengaruh dan penyuapan ditampilkan dalam tabel 1 .

\section{Bagaimana ke Depan?}

Sebagai negara yang telah meratifikasi UNCAC, sudah menjadi konsekuensi yuridis untuk mengimplementasikasikan norma-norma esensial ke dalam hukum positif. Selain sebagai bentuk komitmen atas ratifikasi UNCAC, implementasinya dalam hukum nasional juga menjadi langkah perbaikan yuridis atas pemberantasan korupsi di Indonesia. Terlebih, modus operandi korupsi saat ini tidak hanya dalam bentuk yang telah diakomodasi dalam UU PTPK, seperti merugikan keuangan negara, suap, gratifikasi dan lainnya, tetapi juga, dan ini yang paling mengkhawatirkan, korupsi yang pada substansinya membajak fungsi-fungsi otoritas publik untuk kepentingan

28 Manohara, "Dagang Pengaruh", hlm. 63.

29 Rikky Adhi Susilo, Bambang Sugiri, dan Ismail Novianto, "Kriminalisasi Perdagangan Pengaruh (Trading in Influence) Sebagai Tindak Pidana Korupsi”, http://hukum.studentjournal.ub.ac.id/index.php/hukum/ article/view/2022/1358, 2016, diakses 14/2/2020. Jurnal Hukum, 16, 1 (2016), hlm. 3.

30 Nefa Claudia Meliala, "Urgensi Kriminalisasi Perdagangan Pengaruh dalam Pembaharuan Hukum Pidana", https://www.hukumonline. $\mathrm{com} /$ berita/baca/lt5c45574b1e6e9/urgensi-kriminalisasi-perdaganganpengaruh-dalam-pembaharuan-hukum-pidana-oleh-nefa-claudia-meliala/, $21 / 1 / 2019$, diakses $31 / 1 / 2020$. 
bisnis, politik, ataupun gabungan dari keduanya (state capture). ${ }^{31}$

Kebijakan untuk mengadopsi ketentuan memperdagangkan pengaruh ke dalam hukum positif bisa dilakukan melalui dua alternatif: revisi KUHP atau revisi UU PTPK. ${ }^{32}$ Melalui revisi KUHP, keberadaan pasal yang mengatur mengenai memperdagangkan pengaruh pernah masuk dalam RKUHP, namun dalam Rancangan tahun 2019 tidak ditemukan lagi. ${ }^{33}$ Karena itu, akomodasi melalui revisi UU PTPK dipandang lebih tepat untuk diupayakan ke depannya.

Pengaturan perbuatan memperdagangkan pengaruh dalam RKUHP sendiri sebenarnya kurang tepat, walaupun politik hukum yang dibangun adalah melakukan kodifikasi Undang-Undang Hukum Pidana. Pertama, perbuatan tersebut jika dimasukkan dalam kodifikasi (dalam hal ini adalah KUHP) akan merusak sistem kodifikasi tersebut. ${ }^{34}$ Sebagai contoh, dalam UU PTPK, perbuatan percobaan, pembantuan dan permufakatan jahat dalam melakukan tindak pidana korupsi diancam dengan pidana yang sama dengan pelaku inti, ${ }^{35}$ Sedangkan dalam KUHP, perbuatanperbuatan tersebut ancaman pidananya dikurangi sepertiga. Kedua, sulit untuk melakukan perubahan dalam KUHP, disebabkan upaya revisi KUHP sudah sangat lama ingin dilakukan namun tidak pernah tuntas. Hal ini tentu berisiko jika mengingat maraknya perbuatan memperdagangkan pengaruh yang terjadi di Indonesia. Karena itu, akomodasi melalui revisi UU PTPK, yang merupakan ketentuan

31 Faris, dkk., Kajian Implementasi Aturan Memperdagangkan Pengaruh, hlm. 41.

32 Pengaturan hukum pidana di Indonesia memang ada yang terdapat dalam KUHP dan ada yang tersebar dalam berbagai undang-undang di luar KUHP. Meski demikian, yang paling penting sesungguhnya adalah pengaturan hukum pidana tersebut dilakukan dalam kerangka unifikasi hukum, sehingga terjadi pensenafasan dan kesejiwaan antarketentuan. Mompang L. Panggabean, "Kebijakan Legislatif dalam Hukum Pelaksanaan Pidana di Indonesia”, Masalah-Masalah Hukum, 41, 2 (2012), hlm. 196.

33 Bagian ketiga Rancangan Undang-Undang Hukum Pidana Tahun 2019.

34 Orpa Ganefo Manuain, "Pertanggungjawaban Pidana Korporasi dalam Tindak Pidana Korupsi” (tesis, Universitas Diponegoro, Semarang, 2005), hlm. 2.

35 Pasal 15 UU PTPK. 
khusus dalam hukum pidana, menjadi lebih strategis. Secara historis, pengaturan melalui ketentuan khusus ini juga dijumpai dalam hukum Indonesia, yaitu dalam keadaan yang mendesak dan perlu segera diatur. Misalnya, Peraturan Penguasa Perang Pusat mengenai Pengusutan, Penuntutan dan Pemeriksaan Tindak Pidana Korupsi, yang dikeluarkan ketika seluruh wilayah negara Indonesia dinyatakan dalam keadaan perang ${ }^{36}$ yang kemudian diundangkan dengan Undang-Undang Nomor 1 Tahun $1961 .{ }^{37}$

Oleh karena itu upaya paling tepat adalah mengadopsi ketentuan memperdagangkan pengaruh ke dalam revisi UU PTPK. Upaya untuk mengatur perbuatan memperdagangkan pengaruh ke dalam revisi UU PTPK sebenarnya sudah beberapa kali dilakukan, misalnya dalam Pasal 7 draft Rancangan UU PTPK..$^{38}$ Namun sampai saat ini revisi UU ini belum menjadi prioritas, padahal urgensi revisinya seharusnya dapat memuat pengaturan memperdagangkan pengaruh menjadi hukum positif.

Sebagaimana dikemukakan oleh A. Mulder, kebijakan hukum pidana adalah garis-garis kebijakan untuk menentukan beberapa hal berikut: menentukan seberapa jauh ketentuan hukum pidana yang berlaku perlu diubah atau diperbaharui; menentukan apa yang dapat diperbuat untuk mencegah terjadinya tindak pidana; dan menentukan cara bagaimana penyidikan, penuntutan, dan peradilan dan pelaksanaan pidana harus dilakukan. ${ }^{39}$ Karena itu, ketentuan hukum pidana yang berlaku terkait tindak pidana korupsi sudah semestinya direvisi. Hal ini mengingat Indonesia telah meratifikasi UNCAC pada 2006 sebagai bentuk komitmen untuk memberantas tindak pidana korupsi di Indonesia, sebagaimana yang dicita-citakan sejak awal pembentukan UU PTPK. Ketentuan dalam UNCAC sudah selangkah lebih maju dibanding UU PTPK, terutama pengaturan

36 Keadaan tersebut dinyatakan melalui Undang-Undang Nomor 74 Tahun 1957 jo. Undang-Undang Nomor 79 Tahun 1957.

37 R. Wiryono, Pembahasan Undang-Undang Pemberantasan Tindak Pidana Korupsi” (Jakarta: Sinar Grafika, cetakan kedua, 2009), hlm. 3.

38 Indonesia Corruption Watch, "Naskah Akademik dan Rancangan", hlm. 170.

39 Ravena dan Kristina, Kebijakan Kriminal, hlm. 129. 
mengenai memperdagangkan pengaruh sebagai bentuk korupsi yang terus berevolusi dan pelaku yang selalu berusaha mengelabui hukum dengan cara tidak terlibat secara langsung dalam melakukan tindak pidana. Contoh kasus yang disebutkan dalam artikel ini memperlihatkan pihak yang berkepentingan tidak berhubungan secara langsung dengan otoritas publik untuk mewujudkan kepentingannya namun menggunakan pihak lain yang tidak memiliki kewenangan tetapi bisa mempengaruhi pengambilan kebijakan oleh pejabat publik yang bersangkutan.

Untuk mencegah terjadinya tidak pidana korupsi, selain melalui upaya preventif seperti pendidikan anti korupsi atau gerakan anti korupsi lainnya, ${ }^{40}$ juga diperlukan kebijakan penal. Perkembangan modus operandi tindak pidana korupsi perlu diikuti dengan kebijakan penal sebagai sarana untuk menertibkan dan melindungi masyarakat dari penyalahgunaan fungsi-fungsi negara baik untuk kepentingan pribadi, kepentingan bisnis maupun kepentingan politik. Kebijakan penal terkait memperdagangkan pengaruh menjadi penting jika melihat penyebab timbulnya korupsi. Menurut Ramirez Torres, korupsi tidak hanya sekadar keinginan, namun merupakan kejahatan kalkulasi di mana seseorang akan melakukannya jika hasil yang didapat lebih besar daripada hukuman yang dikenakan serta kemungkinan kecil untuk tertangkap. ${ }^{41}$ Karena itu diperlukan kebijakan penal, untuk mengadili pelaku memperdagangkan pengaruh sekaligus sebagai effect psychologis bagi masyarakat agar tidak melakukan korupsi.

Berkaitan dengan penyidikan, penuntutan dan peradilan, tentu tidak bisa dipisahkan dengan pembuktian. Tujuan dari pembuktian tidak hanya untuk mencari kesalahan seseorang namun juga untuk

40 Upaya pencegahan korupsi dengan pendidikan kepada masyarakat semisal pengenalan bentuk-bentuk korupsi, tentu sangat penting. Misal, pengenalan kepada masyarakat tentang korupsi besar (grand corruption), korupsi sedang (middle class corruption), dan korupsi kecil (petty corruption). Muhammad Rustamaji dan Bambang Santoso, "Interrelationship of Corruption and Ecological Disaster”, Jambe Law Journal, 2, 2 (2019), hlm. 124-129.

41 Bambang Waluyo, Pemberantasan Tindak Pidana Korupsi (Strategi dan Optimalisasi) (Jakarta: Sinar Grafika, 2011), hlm. 21-22. 
mencari, menemukan, dan menetapkan kebenaran yang ada dalam perkara itu. Indonesia menganut sistem pembuktian yang berdasarkan undang-undang secara negatif (negatief wettelijk), ${ }^{42}$ artinya hakim dapat memutus seseorang bersalah atas keyakinannya yang didasarkan pada suatu kesimpulan yang diperoleh dari sekurang-kurangnya dua alat bukti yang sah. ${ }^{43}$ Memang terdapat kesulitan dalam pembuktian perkara memperdagangkan pengaruh, sebagaimana dikemukakan AAELP. Kesulitan ini terutama dalam membuktikan hubungan kausal antara pihak yang mempengaruhi dengan pihak yang dipengaruhi. Namun demikian, kesulitan ini semestinya bukan menjadi alasan untuk tidak mengkriminaliasinya sebagai perbuatan korupsi.

Berdasarkan argumentasi yang sudah dibangun, artikel ini menawarkan dua kategori dalam perbuatan memperdagangkan pengaruh yang dapat dirumuskan dalam revisi UU PTPK. Pertama, "setiap orang yang dengan sengaja memberi atau menjanjikan sesuatu baik secara langsung maupun tidak langsung kepada penyelenggara negara/pegawai negeri atau orang lain agar menyalahgunakan pengaruhnya secara nyata atau yang dianggap ada dengan maksud supaya memperoleh keuntungan yang tidak semestinya dari otoritas publikuntuk kepentingannya atau oranglain". Kedua, "penyelenggara negara/pegawai negeri atau orang lain yang meminta atau menerima sesuatu, sebagaimana yang disebut pertama”.

Dengan demikian, penentuan subjek hukum menjadi penting dalam mengategorikan perbuatan tertentu sebagai memperdagangkan pengaruh. ICW merumuskan subjek hukum di sini sebagai berikut: ${ }^{44}$

1. Pejabat publik sebagaimana mengacu pada Pasal 1 angka 8 Undang-Undang Keterbukaan Infomasi Publik;

2. Ketua umum partai politik dan strukturnya ke bawah;

3. Orang yang memiliki hubungan kekeluargaan dengan pejabat

42 Andi Muhammad Sofyan dan Abd. Asis, Hukum Acara Pidana: Suatu Pengantar (Jakarta: Kencana, cetakan ketiga, 2017), hlm. 234.

43 Pasal 183 Kitab Undang-Undang Hukum Acara Pidana.

44 Faris, dkk., Kajian Implementasi Aturan Memperdagangkan Pengaruh, hlm. 45. 
publik; dan

4. Pengusaha.

Perumusan tersebut menjadi logis mengingat pengaruh memang dapat berupa tekanan secara politik maupun secara ekonomi. Untuk membuktikan adanya "penyalahgunaan pengaruh" oleh seseorang kepada pejabat publik, penting untuk melihat dan menemukan fakta-fakta bahwa terdapat ketimpangan kuasa antara orang yang dipengaruhi dan orang yang mempengaruhi sehingga dapat dibuktikan pengambilan keputusan oleh pejabat publik diintervensi oleh tekanan dari pihak lain.

Implementasi aturan memperdagangkan pengaruh ke dalam revisi UU PTPK juga berdampak pada penegak hukum yang berwenang menangani kasus tersebut. Jika pengaturan memperdagangkan pengaruh diatur dalam KUHP, KPK menjadi tidak memiliki kewenangan menanganinya. Namun, jika diatur dalam UU PTPK, KPK berarti memiliki kewenangan untuk menanganinya. Dengan kewenangan penanganan ada pada KPK, maka akan mempermudah pembuktiannya, terutama terkait kewenangannya melakukan penyadapan, yang bisa menjadi alat bukti petunjuk sehingga akan mempermudah dalam mengetahui dan membuktikan perbuatan pelaku.

\section{E. Kesimpulan}

Berdasarkan pembahasan diketahui bahwa perbuatan memperdagangkan pengaruh belum diatur dalam hukum pidana Indonesia, namun sebenarnya sudah diatur dalam Konvensi. Dalam hukum pidana Indonesia, ketentuan tentang perbuatan memperdagangkan pengaruh tidak ditemukan dalam Undang-Undang Pemberantasan Tindak Pidana Korupsi maupun Kitab Undang-Undang Hukum Pidana. Dalam Konvensi Internasional, ketentuan tentang perbuatan memperdagangkan pengaruh ditemukan dalam United Nations Convention Against Corruption, dan Indonesia telah meratifikasinya melalui Undang-Undang Nomor 7 Tahun 2006. Namun demikian, pemerintah Indonesia sampai saat ini belum mentransformasikannya 
ke dalam hukum nasional. Hal demikian dikarenakan sifat non mandatory dalam ketentuan Konvensi, dan juga tampaknya kesulitan dalam mengidentifikasi perbuatan tersebut. Sebagai bentuk trilateral relationship dari korupsi, pelaku dalam perbuatan ini sulit diidentifikasi karena pihak yang berkepentingan dan pihak yang berbuat tidak berhubungan langsung, melainkan memanfaatkan pengaruh pihak lain agar memengaruhi otoritas publik dalam pengambilan keputusan. Sebagai bagian dari pembaruan hukum pidana, ke depan dipandang urgen untuk mengadopsi ketentuan memperdagangkan pengaruh dalam Konvensi ke dalam hukum positif, dalam hal ini yang paling strategis melalui revisi Undang-Undang Pemberantasan Korupsi. Terlebih lagi dalam beberapa kasus korupsi di Indonesia selama ini sebenarnya terkait dengan perbuatan memperdagangkan pengaruh, seperti kasus penambahan kuota impor daging serta kasus jual beli jabatan di Kementerian Agama, sebagaimana yang dibahas dalam artikel ini.

\section{Daftar Pustaka}

\section{Artikel, Buku, dan Laporan}

Arief, Barda Nawawi. Bunga Rampai Kebijakan Hukum Pidana. Bandung: Citra Aditya Bakti, 1996.

Association of Certified Fraud Examiner. "Trading in Influence, Telah Diratifikasi tetapi belum Diterapkan di Indonesia”. Https:// acfe-indonesia.or.id/2018/02/trading-in-influence-telahdiratifikasi-tetapi-belum-diterapkan-di-indonesia/, 15/2/2018. Diakses 31/1/2020.

CNN Indonesia. "Eks Ketum PPP Romahurmuziy Divonis Dua Tahun Penjara”. Https://www. cnnindonesia.com/ nasional / $20200120101934-12-466884$ / eks-ketum-pppromahurmuziy- divonis-dua-tahun-penjara, 20/1/2020. Diakses $16 / 2 / 2020$.

Farid, Zainal Abidin. Hukum Pidana 1. Jakarta: Sinar Grafika, cetakan keempat, 2014.

Faris, Donal, Almas Sjafrina, Era Purnama sari, dan Wahyu Nandang 
Herawan. Kajian Implementasi Aturan Memperdagangkan Pengaruh dalam Hukum Nasional. Jakarta: Indonesia Corruption Watch, Lembaga Bantuan Hukum Padang, dan Yayasan Lembaga Bantuan Hukum Indonesia, 2014.

Hamzah, Andi. Pemberantasan Korupsi Melalui Hukum Pidana Nasional dan Internasional. Jakarta: Rajawali Pers, cetakan ketujuh, 2015. Juwana, Hikmahanto. "Kewajiban Negara dalam Proses Ratifikasi Perjanjian Internasional: Memastikan Keselarasan dengan Konstitusi dan Mentransformasikan ke Hukum Nasional”. Undang: Jurnal Hukum, 2, 1 (2019): 1-32. DOI: 10.22437/ujh.2.1.132.

Lasmadi, Sahuri, Usman, dan Elly Sudarti. "Modus Operandi Pelaku Tindak Pidana Korupsi yang Dilakukan Anggota DPR dalam Pelepasan Kawasan Hutan Lindung Pantai Air Telang Kabupaten Banyuasin Sumatera Selatan”. Jurnal Komunikasi Hukum, 5, 1 (2019): 1-20. DOI: 10.23887/jkh.v5i1.16748.

Manalu, Andreas Nathaniel. "Kriminalisasi 'Trading in Influence'

Melalui Ketentuan Suap (Analisis Putusan Perkara Tindak Pidana Korupsi No. 38/PID.SUS /TPK/2013/PN.JKT.PST atas Terdakwa Lutfi Hasan Ishaq". Anotasi Putusan Tindak Pidana Korupsi, 2015.

Manohara, Brigita P. Dagang Pengaruh: Trading in Influence di Indonesia. Jakarta: Rajawali Pers, 2017.

Manuain, Orpa Ganefo. "Pertanggungjawaban Pidana Korporasi dalam Tindak Pidana Korupsi”. Tesis, Universitas Diponegoro, Semarang, 2005.

Meliala, Nefa Claudia. "Urgensi Kriminalisasi Perdagangan Pengaruh dalam Pembaharuan Hukum Pidana”. Https: / / www. hukumonline.com/berita/baca/lt5c45574b1e6e9/ urgensikriminalisasi-perdagangan-pengaruh-dalam-pembaharuanhukum-pidana-oleh-nefa-claudia-meliala, 21/1/2019. Diakses $31 / 1 / 2020$.

Panggabean, Mompang L. "Kebijakan Legislatif dalam Hukum Pelaksanaan Pidana di Indonesia”. Masalah-Masalah Hukum, 41, 2 (2012): 189-197. DOI: 10.14710/mmh.41.2.2012.189-197. 
Ravena, Dey dan Kristina. Kebijakan Kriminal (Criminal Policy). Jakarta: Kencana, 2017.

Rohcahyanto, Fitroh. "Memperdagangkan Pengaruh sebagai Tindak Pidana Korupsi”. Disertasi, Universitas Airlangga, Surabaya, 2018.

Rustamaji, Muhammad dan Bambang Santoso. "Interrelationship of Corruption and Ecological Disaster". Jambe Law Journal, 2, 2 (2019): 119-137. DOI: 10.22437/jlj.2.2.119-137.

Saputra, Alvin dan Ahmad Mahyani. "Tinjauan Yuridis Trading in Influence dalam Tindak Pidana Korupsi”. Mimbar Keadilan: Jurnal Ilmu Hukum, (2017): 80-89. DOI: 10.30996/mk.v0i0.2201.

Sofyan, Andi Muhammad dan Abd. Asis. Hukum Acara Pidana: Suatu Pengantar. Jakarta: Kencana, cetakan ketiga, 2017.

Susilo, Rikky Adhi, Bambang Sugiri, dan Ismail Novianto. "Kriminalisasi Perdagangan Pengaruh (Trading in Influence) Sebagai TindakPidana Korupsi”. Http: / / hukum.studentjournal. ub.ac.id/index.php/hukum/article/view/2022/1358, 2016. Diakses 14/2/2020.

Waluyo, Bambang. Pemberantasan Tindak Pidana Korupsi (Strategi dan Optimalisasi). Jakarta: Sinar Grafika, 2011.

Wiryono, R. Pembahasan Undang-Undang Pemberantasan Tindak Pidana Korupsi. Jakarta: Sinar Grafika, cetakan kedua, 2009.

\section{Peraturan dan Putusan Hukum}

Republik Indonesia. Undang-Undang Nomor 20 tahun 2001 tentang Perubahan atas Undang-Undang Nomor 31 tahun 1999 tentang Pemberantasan Tindak Pidana Korupsi. Lembaran Negara Republik Indonesia Tahun 2001 Nomor 134, Tambahan Lembaran Negara Nomor 4150.

Republik Indonesia. Undang-Undang Nomor 7 Tahun 2006 tentang

Pengesahan United Nations Conventian Against Corruption 2003.

Lembaran Negara Republik Indonesia Tahun 2006 Nomor 32, Tambahan Lembaran Negara Nomor 4620.

Republik Indonesia. Undang-Undang Nomor 19 Tahun 2019 tentang

Perubahan Kedua atas Undang-Undang Nomor 30 Tahun 
2002 tentang Komisi Pemberantasan Tindak Pidana Korupsi. Lembaran Negara Republik Indonesia Tahun 2019 Nomor 197, Tambahan Lembaran Negara Nomor 6409.

Republik Indonesia, Mahkamah Agung. Putusan Nomor 1195 K/

Pid.Sus / 2014, perkara tindak pidana korupsi pada tingkat kasasi terhadap Lutfi Hasan Ishaq.

Republik Indonesia, Pengadilan Negeri Jakarta Pusat. Putusan Nomor 38/Pid.Sus/TPK/2013/ PN.Jkt.Pst., perkara tindak pidana korupsi terhadap Lutfi Hasan Ishaq.

Republik Indonesia, Pengadilan Negeri Jakarta Pusat. Putusan Nomor 87/Pid.Sus.TPK/2019/PN.Jkt.Pst., perkara tindak pidana korupsi terhadap Muchammad Romahurmuziy. 